\title{
DEVELOPMENT OF INNOVATION IN FIELD of Precision Agriculture
}

\author{
Aleksandar Vekic ${ }^{\mathrm{a}}$, Jelena Borocki ${ }^{\mathrm{a}}$, Stevan Stankovski ${ }^{\mathrm{a}}$ \& Gordana Ostojic ${ }^{\mathrm{a}}$
}

${ }^{a}$ University of Novi Sad, Faculty of Technical Sciences,

Trg Dositeja Obradovica 6, 21000 Novi Sad, Republic of Serbia
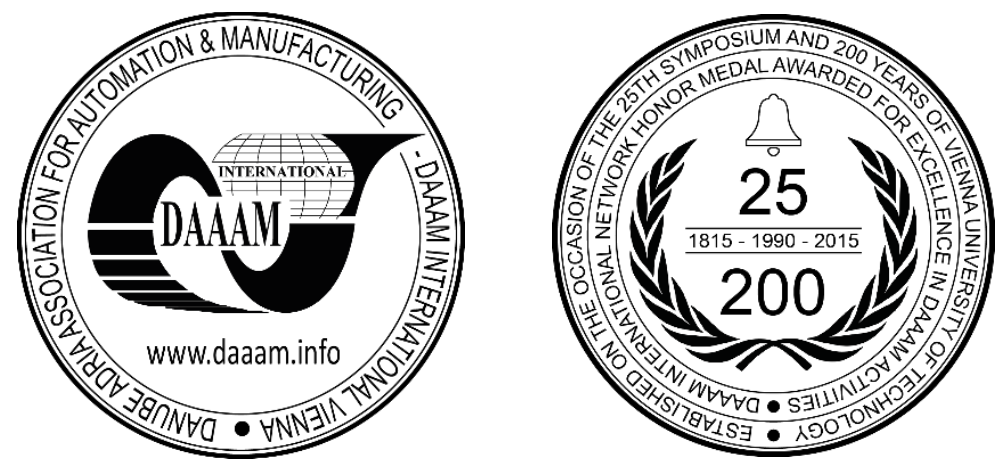

This Publication has to be referred as: Vekic, A[leksandar]; Borocki, J[elena]; Stankovski, S[tevan] \& Ostojic, G[ordana] (2017). Development of Innovation in Field of Precision Agriculture, Proceedings of the 28th DAAAM International Symposium, pp.0787-0795, B. Katalinic (Ed.), Published by DAAAM International, ISBN 978-3-90273411-2, ISSN 1726-9679, Vienna, Austria

DOI: 10.2507/28th.daaam.proceedings.111

\begin{abstract}
Important changes in technology have brought great progress both in the development of precision and future agriculture. Modern systems have facilitated functioning of the whole process and led to increased yields and benefits for all participants in the chain. Innovations in the field of precision agriculture are recognized as an important lever of development, and as such supported various programs by the EU funds. The importance of this support is reflected in very good results, and constant progress of the sector since its inception in the 80's of the 20th century. The aim of this paper is to show the importance of innovation in precision agriculture to the participants in the process, and for society on the whole.
\end{abstract}

Keywords: Precision Agriculture; Growth; Innovations; EU support

\section{Introduction}

This paper focuses on innovation in the area of Precision Agriculture and give reviews of modern solutions which are implemented for this purpose. Dynamic changes in all areas of human life have changed the views and ways of doing certain jobs, especially those of the traditional ones. The effort to reduce the amount of time spent and investing in a particular area always leads to the rapid development of innovation. Innovative activity is always inherent in human society, so many authors try to explain the notion of innovation. Some definitions of innovation are [1]: Schumpeter (1930) explains innovation" as process of introducing a new product or modifications brought to an existing product". Drucker (1954) considers that innovation is „one of two basic functions of an organization“. Simmonds (1986) theoretical view of innovation is: „Innovations are new ideas that consist of: new products and services, new use of existing products, new markets for existing products or new marketing methods, and that is basic creative process“. For Devenport (1991) innovations are: „Complete a task development in a radically new way“. Authors: Covin şi Slevin (1991), Lumpkin and 
Dess (1996), Knox (2002) defined innovation as „A process that provides added value and a degree of novelty to the organization, suppliers and customers, developing new procedures, solutions, products and services and new ways of marketing“. For Rogers (1998):“ innovation involves both knowledge creation and diffusion of existing knowledge“. For European Union innovations are the basis of future development so main institution such as The European Commission gave definition (1999) of innovation as: „Successful production, assimilation and exploitation of novelty in the economic or social environment".

According to Thrott (2005):“ An innovation is an idea that has been transformed into practical reality“ [2]. Authors Tidd \&Bessant state that , Innovation is driven by the ability to see connections, to spot opportunities and to take advantage of them" [3]. Many of huge multinational companies all potential for their development and growth can find in innovation. For example, Siemens company state: Innovation is our lifeblood“[4], the founder of Apple company Steve Jobs, is quoted as saying ,innovation distinguishes between a leader and a follower“ [5]. Richard Brenson, the founder of Virgin Group, said, that: „An innovative business is one which live breathes „outside the box“. It is not just good ideas, it is a combination of good ideas, motivated staff and an instinctive understanding of what your customers want" [6].

Strong growth and development of the ICT sector (including software and hardware) has enabled a high degree of change in all spheres, even in the field of agriculture. One of the reasons for higher development of agriculture segment is growing of the global population, and that causes a changed perspective of development. The concept of technological innovation is particularly important for the development of Precision Agriculture. OECD gave the next definition of technological innovations: "Technological innovations comprise new products and processes and significant technological changes of products and processes. An innovation has been implemented if it has been introduced on the market (product innovation) or used within a production process (process innovation). Innovations therefore involve a series of scientific, technological, organizational, financial and commercial activities" [7]. So product and process innovation are associated with the concept of the technological innovation.

According to Oslo Manual, these two types of innovation are defined as [8]:

- A product innovation is the introduction of a good or service that is new or significantly improved with respect to its characteristics or intended use. This includes significant improvements in technical specifications, components and materials, incorporated software, user friendliness or other functional characteristics.

- A process innovation is the implementation of a new or significantly improved production or delivery method. This includes significant changes in techniques, equipment and/or software.

The future brings an opportunity for unimaginable development of Precision Agriculture, using modern technologies and increasing improvements of mobile platforms which support this kind of managing in agriculture production and storage process. It is clear that innovation is the basis for development of Precision Agriculture, therefore it is very important to study the possibilities that their implementation can bring.

\section{Methodology}

This paper presents insight into the area of Precision Agriculture with modern solutions and systems, and possibilities for innovation for this purpose. We collected a data through this research by using relevant literature and other open sources. We used our own experience too, collected through development of different solutions and applications in this field. Data which used for this purpose are from European Parlament Study about Agriculture and Rural development from 2014. This study is the largest European report about Precison Agriculture, and the name of the study is: Precision Agriculture: An opportunity for EU farmers, potential support with the CAP 2014-2020. The study was developed within Directorate - General for internal policies, Policy department B - structural and cohesion policies.

\section{Precision Agriculture - A new era of agriculture innovation}

In the middle of 80s, the notion of Precision Agriculture emerged and began with sensors for soil matter, and have quickly diversified to include satellites, aerial, and hand held or tractor mounted sensors [9]. The world's population has reached 7,5 billion people, therefore food needs are growing. Limited availability of agricultural resources and capability of supply chain result in a search for new ways in the production of agricultural products.

Bearing in mind the digital revolution we are witnessing, it is clear that most of the answers to some important questions can be found right in this domain. The technological development in Precision Agriculture has been rapid since the 90s, and it continues through the development of the ICT sector. This kind of development has significantly changed the perspectives of agriculture's future.

Precision Agriculture can be understood as: „An integrated information- and production-based farming system that is designed to increase long-term, site-specific and whole-farm production efficiency, productivity and profitability while minimizing unintended impacts on wildlife and the environment" [10]. This definition understood PA in a context of ,whole farm“ management strategy, not in terms of individual farms or crop fields. It's also common definition: „PA is form whereby decisions on resource application and agronomic practices are improved to better match soil and crop requirements as they vary in the field" [10]. According to this definition, the main idea is that PA involving management strategy and focus is on the decision making. The main goal of the concept is to improve production 
management and to limited impact of environment, especially in changeable climatic conditions which are typical of today's life. This kind of agriculture requests using of modern information technology and technical solutions, with a goal of providing benefits, such as: economic, environmental and social.

The objectives of PA can be illustrated:

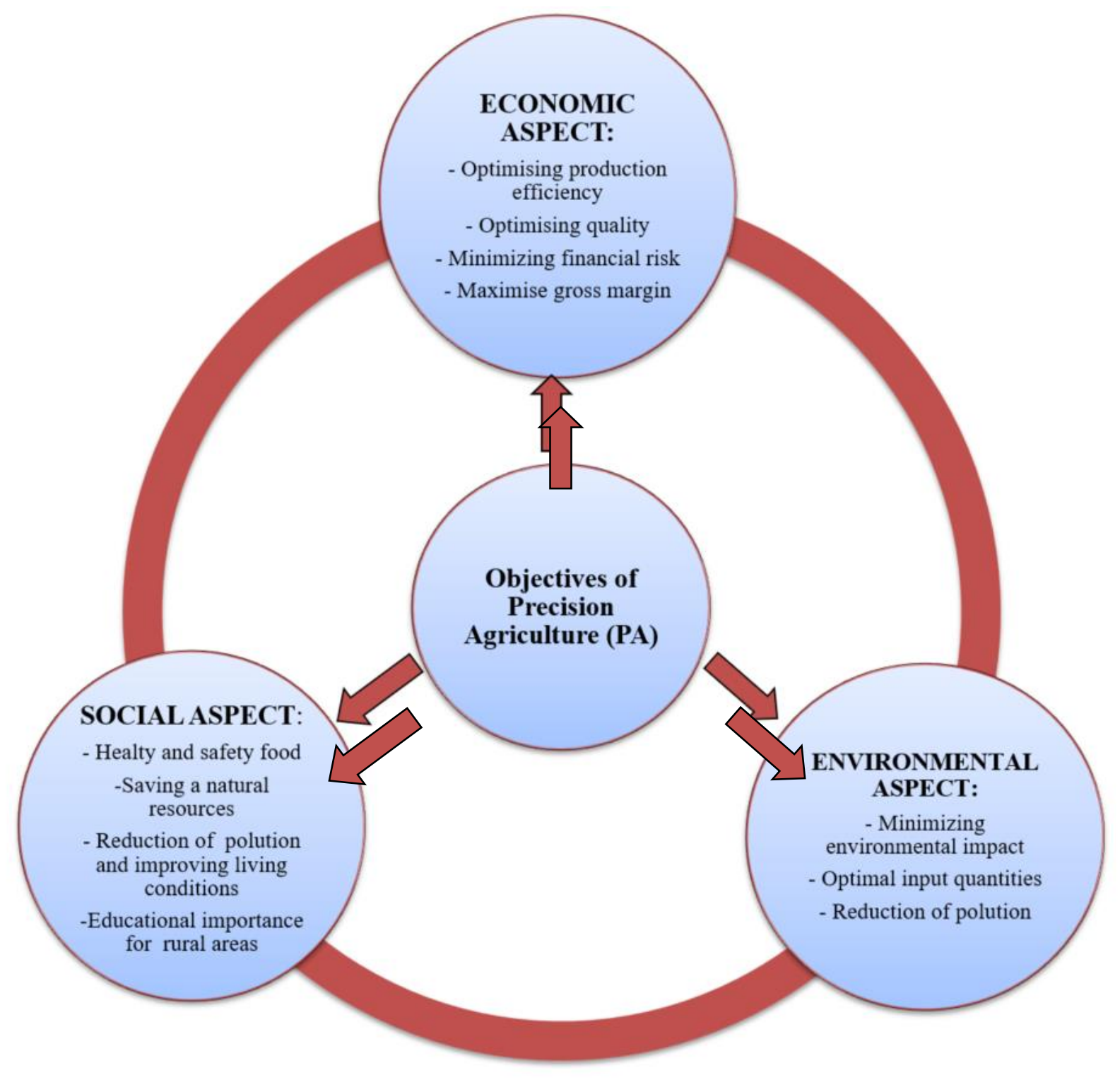

Fig. 1. Objectives of Precision Agriculture (PA) [10]

The primary goal for the development of Precision Agriculture is to make measurements of important parameters such as: temperature, humidity, soil moisture and acidity, reduction of pesticides and fertilizers use, in order to get higher yields and a higher level of quality. It's very important to satisfy requests of economic and environmental aspects. For farmers are very important to take care about basic components of PA [11]:

- Background data - means data about crop production fields and help to make important decisions. The sources of this data can be: grid soil samples, detailed soil mapping, aerial photography, topographic maps, yield maps, soil texture maps, environmentally sensitive areas.

- A recordkeeping system - allows the storage of large amounts of data that are later used in the process and decision making. Usually, special software or external data warehouses such as clouds are used for this purpose.

- Analysis and decision making process - this is a crucial step in developing Precision Agriculture. It is often necessary to analyze huge amounts of data and do their systematization. With the development of IT sector, special web and mobile platforms are developed to perform this complex task and help in making the decision as simple as possible. 
- Specialized implementation equipment - this is precondition to perform tasks within precision agriculture. Development and innovation of the modern equipment have been always in the progress, and that providing more precision data with a higher usage value. Equipment usually includes: GPS guidance systems, equipment for yield monitoring, variable rate application equipment, special types of sensors, different cameras and photo equipment, drones, etc.

- Evaluation and revision- Continuing learning and gaining experience are inseparable part of the process. This is very important, especially after harvest season, and that help farmers to create precision and achievable agriculture plan for the next season.

Within these process components, there are continuous improvement and innovation. This is essential for maintaining the vitality of the entire concept of Precision Agriculture. This implies monitoring of the development of modern and applied technologies and analyzing current trends. Most innovations in precision agriculture are led by big agriculture companies, smaller innovative agricultural technology companies and top agriculture universities and institutes [12]. Innovation in this sphere requires a higher level of investment, but they are very much in demand until their commercialization and return of investing funds.

Most of the funds are spent in the development and implementation of adequate equipment and modern services for its functioning. Their development plays a key role in achieving innovation goal. In the following table, we will show the most important technologies used in the field of Precision Agriculture, their purpose and benefits:

\begin{tabular}{|c|c|}
\hline Type of technology & Purpose and benefits \\
\hline Computational decision tools & $\begin{array}{l}\text { Use data to develop recommendations for management } \\
\text { and optimize multitudes of farm tasks. }\end{array}$ \\
\hline The cloud & $\begin{array}{l}\text { Provide efficient, inexpensive, and centralized data } \\
\text { storage, computation, and communication to support } \\
\text { farm management. }\end{array}$ \\
\hline Sensors & $\begin{array}{l}\text { Gather information on the functioning of equipment and } \\
\text { farm resources to support management decisions }\end{array}$ \\
\hline Robots & $\begin{array}{l}\text { Implement tasks with efficiency and minimal human } \\
\text { labour. }\end{array}$ \\
\hline $\begin{array}{l}\text { Digital communication tools (mobile, broadband, } \\
\text { LPWAN) }\end{array}$ & $\begin{array}{l}\text { Allow frequent, real-time communication between farm } \\
\text { resources, workers, managers, and computational } \\
\text { resources in support of management }\end{array}$ \\
\hline Geo-locationing (GPS, RTK) & $\begin{array}{l}\text { Provide precise location of farm resources (field } \\
\text { equipment, animals, etc.), often combined with } \\
\text { measurements (yield, etc.), or used to steer equipment to } \\
\text { locations. }\end{array}$ \\
\hline Geographic information systems & $\begin{array}{l}\text { Use computerized mapping to aid inventory management } \\
\text { and to make geographical crop input prescriptions } \\
\text { (fertilizer, etc.). }\end{array}$ \\
\hline Yield monitors & $\begin{array}{l}\text { Employ sensors and GPS on harvesters to continually } \\
\text { measure harvest rate and make yield maps that allow for } \\
\text { identification of local yield variability. }\end{array}$ \\
\hline Precision soil sampling & $\begin{array}{l}\text { Sample soil at high spatial resolution (in zones) to detect } \\
\text { and manage fertility patterns in fields. }\end{array}$ \\
\hline
\end{tabular}




\begin{tabular}{|c|c|}
\hline Spectral reflectance sensing (proximal and remote) & $\begin{array}{c}\text { Measure light reflectance of soil or crop using satellite, } \\
\text { airplane, or UAS, imaging, or field equipment-mounted } \\
\text { sensors, to make determinations on soil patterns, crop, or } \\
\text { Animal performance, or on nutrient/pest problems. }\end{array}$ \\
\hline Auto-steering and guidance & $\begin{array}{c}\text { Reduce labour or fatigue with self-driving technology for } \\
\text { farm equipment (including robots); can also precisely } \\
\text { guide equipment in fields to enable highly accurate crop } \\
\text { input placement and management. }\end{array}$ \\
\hline Variable rate technology & $\begin{array}{c}\text { Allow continuous adjustment of application rates to } \\
\text { precisely match localized crop needs in field areas with } \\
\text { field applicators for crop inputs (chemicals, seed, etc.). }\end{array}$ \\
\hline Radio frequency ID & $\begin{array}{c}\text { Collect and process field data with specialized computer } \\
\text { hardware and software on tractors, harvesters, etc., often } \\
\text { connected to sensors or controllers. }\end{array}$ \\
\hline Automated milking, feeding, and monitoring systems & $\begin{array}{c}\text { collect basic biometric data on animals, thereby reducing } \\
\text { labour needs and facilitating individualized animal } \\
\text { management. }\end{array}$ \\
\hline $\begin{array}{c}\text { Pransmit identity data with tags attached to production } \\
\text { units (mostly animals) that allow data collection on } \\
\text { performance as well as individualized management. }\end{array}$ \\
\hline
\end{tabular}

Table 1. Enabling technologies for Precision Agriculture [12]

Very important part of the Precision Agriculture concept is the Remote Sensing Technology. This modern technology provides a huge range of data which are important for agriculture, such as data about: temperature, soil, moisture analysis, monitoring of crop growth, yield forecasting, etc.

This data can be used by national governments, in order to make important decisions and implement them into their agricultural policy. Individual farmers can also use this valuable data which are collected by remote sensing technology, when dealing with their individual crops, about their health status and how to deal with any problems. It is especially important that this data allows farmers to make rough estimates to the final crop yield just by looking at the plant and health status half-way through the season and taking into account the climatic conditions up until that point.

Introduction of this technology always requests detailed planning of agricultural business and making decisions for the next period. Remote sensing can be used for Precision Agriculture in a number of ways by providing input on soil and plant condition and variability in the overall management and decision support system [13]. Remote sensing can significantly contribute to providing a timely and accurate picture of the agricultural sector, as it is very suitable for gathering information over large areas with high revisit frequency [14].

This equipment can provide recorded data in real time. Prior to seeding, air photos, multi-spectral scanners, or high resolution satellite imagery can be used to translate results from point soil test samples, acquired using a grid or stratified sampling scheme, to a spatial coverage for the whole field [13].

Some possibilities of modern solutions of Precision Agriculture are illustrated on following pictures: 


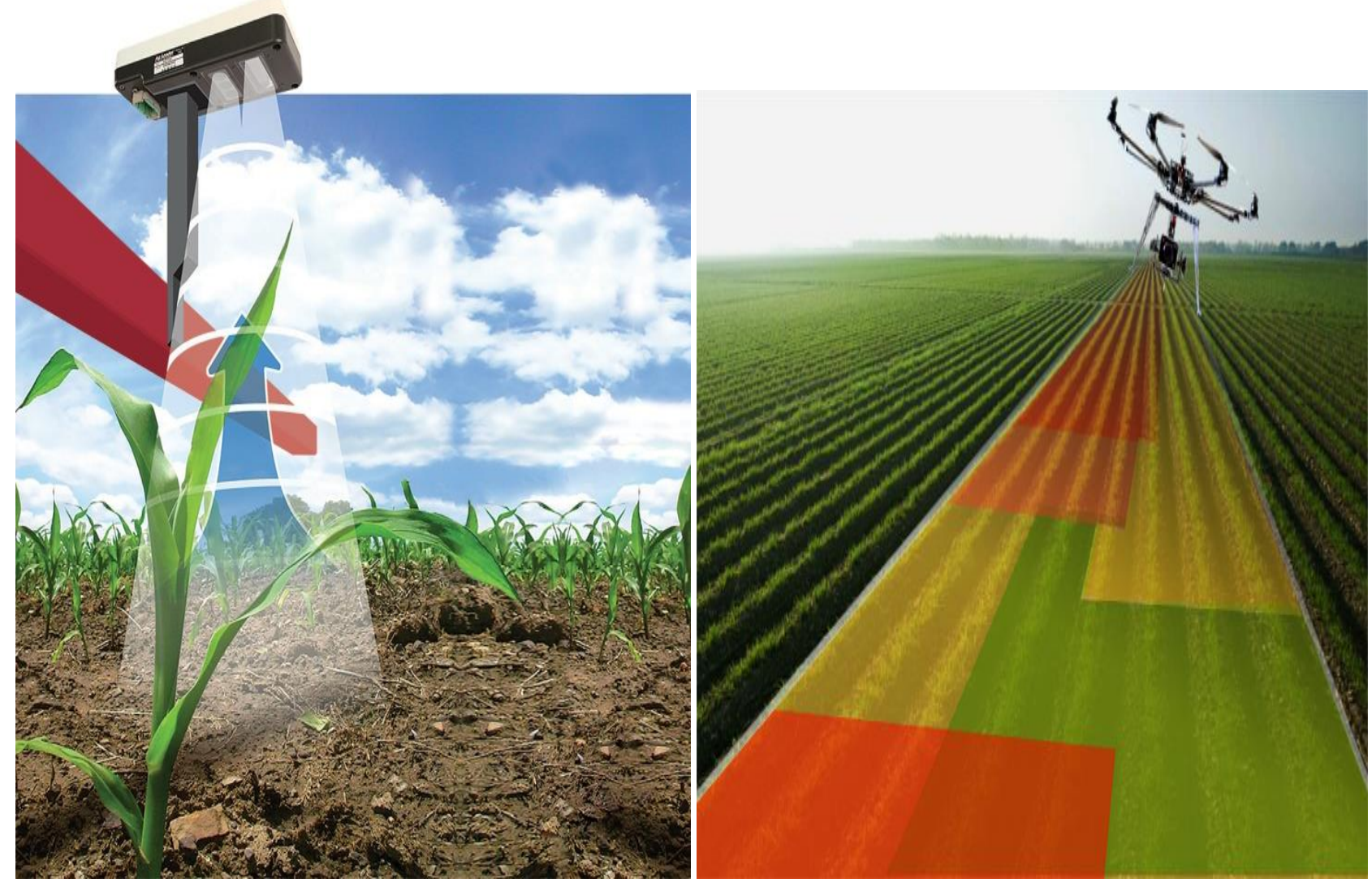

Fig. 2. The use of sensors and drones (with spectral camera) on the crop filed for Geothermal analysis [15] [16]

Optimal combination of shown technologies and services leads to the positive growth of all the most important parameters that are observed. Some researchers predict that digital data will be getting collected at the rate of 40 zettabytes $(1 \mathrm{ZB}=$ 40 trillion GB) per year by 2020 [17]. This is a huge potential for the Precision Agriculture, and it is to be expected that these opportunities will be exploited in the best possible way. The primary goal of Precision agriculture is to enable the production of enough food for the growing world population, according to UN data world population will reach 9,6 billion by 2050 [18]. Development of agricultural technologies requires knowledge (ranging from broad to specific) and talent in science and entrepreneurship [12].

\section{The main benefits of agricultural innovation and EU support}

PA nowadays is seen as an "environment friendly system solution that optimizes product quality and quantity while minimizing cost, human intervention and the variation caused by the unpredictable nature" [19]. It's very important to understand the applicability technologies in Precision Agriculture and to gain knowledge of how to use them in the best way. Their implementation leads to more efficient: decision-making process, monitoring soil and plant parameters, collecting real time data, reducing waste and the chemicals in the production process, automated field management, increase profit, protection of the environment, use of labor and resources, adapting to regulations, etc. For a successful business, farms must increase their arable land, reduce risk of crop failure, minimize operating costs, reach the highest price for their products, work on expanding their market, etc.

The precision farming market is expected to grow, at a CAGR (Compound annual growth rate), of $13.47 \%$ between 2016 and 2022 [20]. Some research shows that implementation of digital technology in agriculture can increase overall profitability by $55 \$$ to $110 \$$ per acre $(1$ acre $=0,40$ ha) [21]. The global market for Precision Agriculture is expected to be around 3.7 billion euros in 2018 [22]. By using the modern applications and management tools, the farmer can easily obtain data on profitability and the impact that the application of modern solutions has on his business and the expected returns. This allows farmers to gain a higher level of competitive advantage and become more dominant in the market. It's estimated that over 50 percent of growers currently engage in some form of Precision Agriculture Technology [23]. Agriculture retailers have the opportunity to help their customers by providing them with local expertise on how the various technologies available today, might best be implemented within their geography and more specifically within their individual operation to help them improve their return on investment in the most appropriate ways [23].

The following table shown relationship between costs and benefits: 


\begin{tabular}{|c|c|c|}
\hline & Costs & Benefits \\
\hline Background data & $\begin{array}{l}\text { Time is required to collect data or pay } \\
\text { a consultant for the service. Soil } \\
\text { sampling generally costs } \$ 3-7 / a \text {, but } \\
\text { can be considerably more for the } \\
\text { more intensive collection. Other } \\
\text { services from a crop consultant are } \\
\text { generally based on an hourly charge. }\end{array}$ & $\begin{array}{l}\text { Data may identify problems and } \\
\text { opportunities the farmer was } \\
\text { unaware of. This can be particularly } \\
\text { true of low-yielding areas or } \\
\text { environmentally sensitive areas } \\
\text { where application of crop inputs } \\
\text { may cause problems. }\end{array}$ \\
\hline Recordkeeping & $\begin{array}{l}\text { Software can range from very little } \\
\text { for shareware or public domain } \\
\text { packages to several thousand dollars } \\
\text { for commercial mapping or } \\
\text { geographic information system } \\
\text { programs. }\end{array}$ & $\begin{array}{l}\text { Organized data allow the farmer to } \\
\text { make logical decisions. }\end{array}$ \\
\hline Analysis and decision-making & $\begin{array}{l}\text { Crop consultants generally charge } \\
\qquad \$ 40-80 / \mathrm{ha} \text {. }\end{array}$ & $\begin{array}{c}\text { The analysis allows the farmer to } \\
\text { make the right economic and } \\
\text { environmental decisions. }\end{array}$ \\
\hline Equipment & $\begin{array}{l}\text { Auto-steer: } \$ 30,000-40,000 \\
\text { Light bar guidance: } \$ 3,000-5,000 \\
\text { Yield monitors: } \$ 4,000-7,000 \\
\text { Variable rate spray/fertilizer } \\
\text { controller: } \$ 2,000-3,000\end{array}$ & $\begin{array}{l}\text { Crop inputs can be reduced and the } \\
\text { environment protected. }\end{array}$ \\
\hline
\end{tabular}

Table 2. Relationship between costs and benefits, according to basic components of PA [11]

The cost types associated with the implementation of PA are [19]:

1) Information costs, related to the necessary investments in the technology, including rental fees for specific hardware or machinery;

2) Costs which involving data processing, specific license fees, software and hardware products for data analysis;

3) Learning costs, mainly due to the additional time required for the farmer to develop management schemes, calibration of the machinery, as well as 'lost' opportunity costs due to inefficient use of the PA technology

The potential benefits from PA can be [19]:

1) Crop yield improvement

2) Optimization of inputs

3) Improvement of management and quality of the work.

One of the most important factors which affects the profitability of a farm is its size. In Europe, there are 4,500 manufacturers with a mix of large multinational companies and numerous SMEs producing 450 different machine types with an annual turnover of $€ 26$ billion and employing 135,000 people directly and a further 125,000 in the distribution and service network.

The European Union continually develops support programs for the development of agriculture as the main pillar of its development. Support programs for development of PA and innovation in this area are contained in Regulation (EU) No 1305/2013 of the European Parliament and of the Council of 17 December 2013. Several of them are available for Member States to support PA development through their R\&D programs [19]:

- $\quad$ Article 17 (Investments in physical assets)

- Article 28 (Agri-environment-climate)

- Article 35 (Co-operation)

- Article 14 (Knowledge transfer and information actions)

- Article 15 (Advisory services, farm management and farm relief services) 
The European Innovation Partnership for Agricultural Productivity and Sustainability (EIP-AGRI) can play an important role in both developing and mainstreaming precision farming in the EU. This program includes: Article 55 (Aims), Article 56 (Operational groups), Article 57 (Tasks). The stated EU report confirmed that Precision Agriculture could play a substantial role in meeting the increasing demand for food while ensuring sustainable use of natural resources and the environment. The Common Agricultural Policy (CAP) is Europe's answer to the need for a decent standard of living for 22 million farmers and agricultural workers and a stable, varied and safe food supply for its 500 million citizens [24]. As a common policy for all 28 EU countries, the CAP strengthens the competitiveness and sustainability of EU agriculture by providing Direct Payments aimed at stabilizing farm revenues and finances projects responding to countryspecific needs through national (or regional) Rural Development Programs, which also cover the wider rural economy [24]. The CAP also provides a range of market measures, including tools to address market difficulties, and other additional elements such as quality logos, promotion for EU farm products which complete CAP action to support farmers [24]. The CAP budget fixed for the period from 2014-2020 provides a total of EUR 408.31 billion, with EUR 308.73 billion intended for direct payments and market measures (the so-called First Pillar) and EUR 99.58 billion for Rural Development (the so-called Second Pillar) [23]. The European Commission promotes precision farming, mostly via its EUR 78 billion through Horizon 2020 program for research.

\section{Conclusion}

Innovation potentials in precision agriculture are enormous, therefore all countries in the world will have to work on strengthening them, in order to achieve greater competitive advantage in this area, as one of the main promoters of growth and development. If we take into account the rapid growth of the population on the planet and the increased need for food, it is clear that any investment in agricultural production will be very profitable but also necessary. Accelerated changes lead to an increase in the number of innovations in all areas of life, even in agriculture that we know today, as it becomes increasingly digital. It is very important to manage these innovations effectively in order to achieve appropriate positive effects in terms of social, economic and environmental aspects. Innovation usually relates to the development of new technologies and equipment, development of new seed types, decision support systems, automation of the business process, introduction of new methods, education of process participants, development of management and new business models, etc. A special subject of research can be to determine the relationship between investment and yielded benefits, based on detailed analysis and creation of cause-consequence models. The specific role in the development of Precision

Agriculture has innovation in Remote Sensing Technology. This technology provides a huge range of data, which can be used for improvement of agriculture business. These technologies are becoming more precise, and the quality of the data obtained is increasing. The growing use of these technologies (especially sensor systems with base stations and drones) in agriculture is noticeable in all developed market economies as well as in emerging countries. In further research, it will be necessary to determine the impact of the application of these technologies on the observed parameters in the multi-annual framework, taking into account the changing conditions. Our predictions are that the development of this area will be very dynamic, with almost automatic effects on the economy and society, at the level of one country, region or the whole world. The European Union is a good example of how much attention needs to be given to the development of agriculture. This process is followed by the number of regulations, development and support programs without which the entire system would not be functional and that requires the investment of enormous assets in order to achieve the set goals. All Member States have an important role in this project. It is necessary to establish a clear mechanism for overcoming the obstacles that accompany this complex process. It will be very interesting to see which further moves will be in terms of defining agriculture policy and their effects in the future. We expect to see in the future: the emergence of new and improved software and hardware systems to support all operations within precision agriculture, the emergence of new partnerships, the development of new agricultural crops, new harvesting approaches, etc.

\section{Acknowledgments}

The authors acknowledge the financial support of the Ministry of Education and Science of the Republic of Serbia, within the Project No. 47028.

\section{References}

[1] Popa, L. I.; Preda, G. \& Boldea, M. (2010). A theoretical approach of the concept of innovation, Managerial Challenges of the Contemporary Society, Vol.1, pp. 151-156, ISSN: 2069-4229.

[2] Trott, P. (2008). Innovation management and new product development, Prentice Hall, ISBN: 9780273713159, London.

[3] Tidd, J. Bessant, J. (2016). Managing innovation: Integrating technological, market and organizational change, Wiley, ISBN: 978-1-118-36063-7, London.

[4] http://www.siemens.dz/en/about/innovation.htm, (2017). Accessed on: 2017-07-07.

[5] http://www.denverleadership.org/wp-content/uploads/2015/02/AR10_11.pdf, (2011). Accessed on: 2017-07-07.

[6] Fitzgerald, B. Wynn, E. (2004). IT innovation for adaptability and competitiveness, Kluwer Academic Publisher, ISBN: 978-1-4020-7999-3, Boston. 
[7] OECD, Oslo manual. (1993). The Measurement of Scientific and Technical Activities, ISSN: 1990-0414, Available from: http://dx.doi.org/10.1787/19900414, Accessed on: 2017-07-07.

[8] Palcic, I.; Koren, R \& Buchmeister, B. (2014). Technical Innovation Concepts is Slovenia Manufacturing Companies, 25th DAAAM International Symposium on Intelligent Manufacturing and Automation, DAAAM 2014, Procedia Engineering 100 (2015), Katalinic, B. (Ed), Published by DAAAM International, pp.141-149, Vienna, Austria.

[9] Mulla, J. D. (2013). Twenty five years of remote sensing in precision agriculture: Key advances and remaining knowledge gaps, Biosystems engineering, Vol. 114, Issue 4, pp. 358-371, ISSN: 1537- 5110.

[10] Whelan, B. Taylor, J. (2013). Precision Agriculture for Grain production systems, CSIRO PUBLISHING, ISBN: 978-0643107472, Collingwood VIC.

[11] USDA, NRCS, East National Support Center, Soil Quality National Technology Development team. (2007), Precision Agriculture: NRCS Support for Emerging Technologies, Agronomy Technical Note No.1, Available from https://www.nrcs.usda.gov/Internet/FSE_DOCUMENTS/stelprdb1043474.pdf, Accessed on: 2017-09-07.

[12] Es Van, H. Woodard, J. (2017). Innovation in Agriculture and Food Systems in the Digital Age, In: The Global Innovation Index 2017- Innovation Feeding the World, pp. 97-104. Cornell University, INSEAD, and the World Intellectual Property Organization (WIPO), ISBN: 979-10-95870-04-3.

[13] Brisco, B. Brown, R.J. Hirose, T. McNairn, H. \& Staenz, K. (2014). Precision Agriculture and the Role of Remote Sensing: A Review, Canadian Journal of Remote Sensing, pp. 315-327 http://dx.doi.org/10.1080/07038992.1998.10855254

[14] Atzberger, C. (2013). Advances in Remote Sensing of Agriculture: Context Description, Existing Operational Monitoring Systems and Major Information Needs, Remote Sensing, pp. 949-981, ISSN 2072-4292.

[15] http://www.homburg-holland.com/nieuws/homburg-holland-on-tour-2016, (2016). Accessed on: 2017-09-27.

[16] http://panamaadvisoryinternationalgroup.com/blog/news-from-panama/drones-in-agriculture/, (2017). Accessed on: 2017-09-27.

[17] Tien, J. M. (2013). Big Data: Unleashing Information, Journal of Systems Science and Systems Engineering, Vol. 22, No.2, pp. 127-151, ISSN: 1004-3756.

[18] Roser, M. Ortiz-Ospina, E. (2017). World population growth, Our world in data, Available from: https://ourworldindata.org/world-population-growth/, Accessed on: 2017-09-27.

[19] European Parlament (2014). Precision agriculture: An opportunity for EU farmers - potential support with the CAP 2014-2020, Publication office, ISBN: 978-92-823-5575-6.

[20] http://www.marketsandmarkets.com/Market-Reports/precision-farming-market-1243.html, (2017). Accessed on: 2017-09-29.

[21] https://www.accenture.com/_acnmedia/Accenture/ConversionAssets/DotCom/Documents/Global/PDF/Digital_3/ Accenture-Digital-Agriculture-Point-of-View.pdf, (2017). Accessed on: 2017-09-29.

[22] https://www.statista.com/statistics/720062/market-value-smart-agriculture-worldwide/, (2017). Accessed on: $2017-$ 30-09.

[23] http://inthefurrow.com/benefits-precision-agriculture/ , (2017). Accessed on : 2017-09-30.

[24] https://ec.europa.eu/agriculture/sites/agriculture/files/cap-in-your-country/pdf/cz_en.pdf , (2016). Accessed on: 2017-09-30. 